\title{
Riksbankens guldkassa
}

Author(s): Knut Wicksell

Source: Ekonomisk Tidskrift, Årg. 16, häft 10 (1914), pp. 263-270

Published by: Wiley on behalf of The Scandinavian Journal of Economics

Stable URL: http://www.jstor.org/stable/3437412

Accessed: 25-06-2016 14:05 UTC

Your use of the JSTOR archive indicates your acceptance of the Terms \& Conditions of Use, available at

http://about.jstor.org/terms

JSTOR is a not-for-profit service that helps scholars, researchers, and students discover, use, and build upon a wide range of content in a trusted digital archive. We use information technology and tools to increase productivity and facilitate new forms of scholarship. For more information about JSTOR, please contact support@jstor.org.

The Scandinavian Journal of Economics, Wiley are collaborating with JSTOR to digitize, preserve and extend access to Ekonomisk Tidskrift 


\section{Riksbankens guldkassa.}

\section{Af Knut Wicksell.}

I tidningen Economist för d. 5 september d. å. stod att läsa ett meddelande, enligt uppgift härrörande från sen hög auktoritet i Stockholm» och gående ut på det önskvärda i, att engelsk kredit tills vidare kunde beviljas åt svenska affärsmän för att afhjälpa den nuvarande bristen på mot utlandet användbara valutor. Att sända guld från Sverige är nämligen, förklarar han, för närvarande omöjligt: „de ro3 mill. kr. i guld, som ligga i riksbanken, äro nödvändiga för sedelutgifningen, ehuru vår bank, följande exemplet af alla andra länder utom England, har inställt sina guldutbetalningar».

Meningen skall förmodligen vara, att dessa hundra millioner äro afsedda att möjliggöra sedelinlösningen vid den tidpunkt i framtiden, då den utan fara kan återupptagas.

Detta kan ju låta plausibelt nog, men är det riktigt? Har storleken af vår guldkassa någon verklig betydelse för våra sedlars inlösbarhet med guld? Genomgår man de uppgifter öfver sedelstockens och guldkassans storlek, som sedan i4 år tillbaka hvarje månad publicerats i Ekonomisk Tidskrift, så finner man det egendomliga förhållandet, att medan sedelstocken alltjämt undergår betydande fluktuationer, ofta med $10 \%$, ja intill $15 \%$ och därutöfver från den ena månaden till den andra, så förblir guldkassan liggande så godt som alldeles orörlig månad efter månad, hela år igenom; variationerna äro så små, att de på ett medelstort diagram knappast ens märkas. På samma gång undergår dock guldkassan tid efter annan en forstoring, vanligen med en eller par millioner $\mathrm{kr}$. i taget, uppenbarligen tillkomna på riksbankens eget initiativ och afsedda att bringa guldkassan i det af lagen föreskrifna förhållandet till den under alla 
svängningar i genomsnitt alltjämt stigande sedelmängden. Genom dessa åtgärder har den $\mathrm{i}$ landet befintliga guldbehållningen under den nämnda tidsperioden efter hand stigit från mindre än 40 millioner år 1899 till de nuvarande några och Ioo millionerna, under det att den utelöpande sedelmängden samtidigt ökats från r 30 à I 40 millioner $\mathrm{kr}$. (riksbankens och de enskilda bankernas dåvarande sedelemission tillsammantagna) till de nuvarande 220 à 240 millionerna, i det jag bortser från den senaste, af kriget och krisen förorsakade utvidgningen af riksbankens sedelutgifning.

Endast vid ett tillfälle under hela denna period har en verklig påkänning på vår guldkassa ägt rum, nämligen under senhösten 1907, då den bekanta amerikanska "guldsugningen» tyckes ha sträckt en sugvårta äfven till vårt aflägsna land med den påföljd, att riksbanken under de sista två månaderna af nämnda år förlorade omkr. 6 millioner af sina dåvarande 77 . Riksbanken besvarade detta attentat genom att höja sin diskontränta till $7 \%$, hvarefter gulduttagningen afstannade. Frampå sommaren och hösten följande år återkom det utsända guldet, och stigningen af guldkassan har sedermera tid efter annan fortgått på samma sätt som förut.

Man torde därför kunna säga, att $\mathrm{i}$ vårt land guldkassans storlek $\mathrm{i}$ verkligheten är utan all betydelse för sedelemissionen eller upprätthållandet af sedlarnas likvärdighet med guld. Denna regleras fastmer uteslutande genom diskontskrufven, hvilket åter sker helt mekaniskt på grund af betalningsbalansens och växelkursens ställning vid hvarje särskild tidpunkt. Den guldsugning från allmänhetens sida, som i andra länder uppträder, så snart rörelsen behöfver mera omsättningsmedel, och som enligt $\mathrm{K}$. Helfferich numera utgör den egentliga orsaken till guldkassornas fluktuationer, är hos oss okänd, då ju guldet icke alls användes i den allmänna rörelsen.

Man kan under sådana omständigheter fråga sig, hvartill hållandet af en så pass stor guldkassa, medförande en årlig ränteförlust af c:a 5 millioner kr., egentligen skall tjäna. Naturligtvis behöfver vårt penningväsen en säkerhetsfond af till utlandet användbara betalningsmedel. Men denna säkerhetsfond skulle uppenbarligen göra samma nytta, om den vore placerad hos banker eller bankirer $\mathrm{i}$ utlandet eller i lätt säljbara obligationer och andra 
värdepapper, ja den skulle i så fall med samma årliga uppoffring kunna vara dubbelt så stor som nu, eftersom dessa tillgodohafvanden eller värdepapper alltid lämnade någon, om också icke så hög, ränta.

På sätt och vis uppfylla vi dock genom hållandet af denna guldkassa ett slags internationell honnörsplikt: så länge guldet förblir värdemätaren, är tillvaron af stora, samlade guldförråd en ledsam nödvändighet; saknades de, så skulle guldet snart bli lika ostadigt i sitt bytesvärde som t. ex. koppar eller tackjärn. Det låter ju då säga sig, att hvarje land bör åtaga sig sin anpart af denna gemensamma börda. För så vidt torde ingenting vara att anmärka mot storleken af vår guldkassa, det är tvärtom lätt att visa, att vi i förhållande till de flesta andra länder (de enskildas guldkassor medräknade) hålla ett proportionsvis litet belopp i guld, så att vi i det afseendet fortfarande så att säga såka på snålskjuts» hos de stora handelsländerna.

Men å andra sidan faller det väl af sig själft, att en kassa är till för att någon gång användas; att vilja uppställa som allmängiltig regel, att guldkassan eller någon viss del däraf aldrig under några omständigheter får vidröras, hör ingenstädes hemma: den är ju dock ingen fetisch eller amulett, utan helt enkelt en fond af bytesmedel, hvilkas uppgift är att gå i byte $\mathrm{i}$ händelse af behof. Ett sådant behof torde just nu föreligga. En stor del af våra industrier har nödgats minska eller helt inställa sin vanliga export till utlandet och hotas därför af nödvändigheten att helt eller delvis inställa sin drift, så vida de ej kunna sättas i tillfälle att arbeta på lager. Men på samma gång finnes intet förnuftigt tvifvel om, att de i en, vi må hoppas, snar framtid skola få förmånlig afsättning icke blott för sin framtida tillverkning, utan därjämte för allt hvad de under mellantiden lyckats uppsamla i förråd. Visserligen kommer den kapitalförstöring, som kriget förorsakar, tvifvelsutan att en tid bortåt $\mathrm{i}$ hög grad minska konsumtionsförmågan för en hel del lyxartiklar; men efter järn och trä måste efterfrågan bli kolossal, då allt skall sättas i stånd, som nu förstöres. Äfven pappersmassa torde komma att gå åt, ty visserligen minskas »läslusten» och därmed tidningarnas upplagor våldsamt efter ett fredsslut, men å andra sidan torde de stora lager af tidningspapper, som utlandets tidningar pläga hålla sig med, blifvit ansenligt för- 
minskade och måste då förnyas. Särskildt i Frankrike lär detta vara fallet; den bekanta tidskriften Revue des deux mondes utkommer f. n. som ett litet tunt häfte - af brist på papper. Det har bl. a. sagts, att vår stenindustri skulle ligga helt nere. Det är beklagligt, om så är förhållandet, och äfven irrationellt, ty sten om någonting kommer väl att behöfvas efter kriget, då alla söndersprängda eller i sjöar och floder vräkta hamnpirer och brohufvuden samt - dess värre - väl äfven fästningsterrasser o. s. v. måste sättas $\mathrm{i}$ stånd. Dessutom förestår ett stort dylikt arbete af rent fredlig karaktär i Holland, hela Zuidersee skall invallas, en flera mil lång damm mot hafvet skall uppföras och beklädas med cement och sten... M. e. o. ett gynnsammare tillfälle än detta att upparbeta lager af våra hållbara exportvaror har troligtvis aldrig funnits, om blott »kapital» kunde åstadkommas, d. v. s. ytterst lifsmedel till arbetarnas underhåll samt de för driften nödvändiga utländska materialierna jämte stenkol.

Rent ekonomiskt sedt vore därför ingenting förmånligare, än om vi kunde för tillfället få utbyta denna ofruktbara fond på Ioo millioner i guld mot fruktbärande varor från utlandet, vi skulle då icke blott bli $\mathrm{i}$ stånd att hålla vår industriella arbetarstam öfver vattnet tills vidare, utan när freden kommer och kusterna rensats från minor, skulle vi genom utskeppande af de tillverkade och uppsparade varuförråden för det första kunna återhämta allt guldet och för det andra förtjäna betydligt, kanhända lika mycket till, i affärsvinster.

Ängsliga själar skola förmodligen invända, att guldkassan måste ligga, där den nu ligger, för att kunna användas i fall af den yttersta nöd, t. ex. om sfienden stode $\mathrm{i}$ landet». Men tydligt är, att om en sådan olycka inträffade, så måste vår räddning - därest den skall sökas i militära ătgärder — bero på de förråd af vapen, ammunition, hästar o. s. v., som kunna finnas samlade i landet, och icke minst på den fysiska kondition, hvari landets arbetande ungdom då befinner sig, vida mer än på något, som vi då $\mathrm{i}$ en hast kunde förskaffa oss utifrån för pengar. F. ö. skulle, om fienden stode $\mathrm{i}$ landet, vår guldkassa förmodligen icke på någon punkt i landet vara synnerligen tryggad mot angrepp; det vore nog bättre om den eller en del däraf då befunne sig på utländsk botten hos makter, med hvilka vi icke låge $\mathrm{i}$ krig. 
Med det sagda har jag visst icke fördristat mig till att gifva våra affärsmän eller statsmän några praktiska råd, därtill känner jag alltför mycket min egen brist på omfattande praktisk erfarenhet. Jag har blott velat taga till orda mot den så vanliga, egentligen från merkantilismens dagar nedärfda öfverskattningen af guldet såsom en med särskilda, hemlighetsfulla krafter utrustad ekonomisk makt, hvilken man därför sist af allt borde göra sig af med. Guldet $\ddot{a} r$ en sådan makt, men endast så länge det får fritt gå i utbyte mot varor och tjänster, $i$ annat fall blir dess makt = noll. En guldkassa, som ligger innestängd, afspärrad från cirkulationen, är ungefär det onyttigaste ting som gifves och kunde lika gärna vara af mässing.

Det förefaller mig därför också, som om vår riksbank skulle ha handlat klokare, om den följt Englands i stället för Frankrikes och Tysklands exempel och fortsatt med sin sedelinlösning, i stället för att stoppa den, så snart banken under krisen vid utbrottet af världskriget förlorade några få millioner $\mathrm{i}$ guld. (I verkligheten förlorade den ju icke dessa pengar, de äro riksbankens tillhörighet lika mycket efteråt som förut, vare sig de utväxlats mot sedlar - i hvilket fall riksbankens sedelskuld till allmänheten $\mathrm{i}$ motsvarande grad minskats - eller utlämnats $i$ form af lån mot tillfredsställande säkerhet.) Den engelska banken har, som bekant, i närvarande stund, trots den fria sedelinväxlingen, en guldkassa, som är större än någonsin förut, detta alldeles oberoende af den tillfälliga emission af sedlar på 20 och Io shillings, som den engelska regeringen samtidigt företagit. (Se härom tillägget vid slutet af denna uppsats.) Men till och med om riksbanken under panikens dagar eller $\mathrm{i}$ och för betalningar till utlandet hade fått sin guldkassa reducerad till hälften, ja till en fjärdedel af dess sedvanliga storlek, så hade man fortfarande haft den omätliga fördelen, att så länge sedelinväxlingen upprätthålles, våra sedlar alltjämt ha samma värde som guldet, under det att $\mathrm{i}$ närvarande stund ingen riktigt kan säga hvad dessa sedlar - lika litet som mark- eller franc-sedlarna - egentligen äro värda. ${ }^{1}$ Denna fördel kan icke öfverskattas; en hvar som rest $i$ utlandet

1 Enligt Le Temps skulle en hundrafrancssedel, som vid pari är värd 8r riksmark, för ett par veckor sedan i marknaden betingat $86 \mathrm{mk}$, men antagligen ha både mark- och francssedlar deprecierats gent emot guldet och alltså mot de engelska sedlarna. 
vet, att man i Berlin och London under senare år plägat få t. o. m. mera för svenska sedlar än för svenskt guld, detta gynnsamma förhållande skulle antagligen ha förblifvit $\mathrm{i}$ det väsentliga orubbadt, därest det varit kändt, att vår riksbank vore fullt besluten att till det yttersta upprätthålla sedelinväxlingen. Än bättre naturligtvis, om en sådan öfverenskommelse hade kunnat träffas samtliga de skandinaviska centralbankerna emellan.

Men om därvid riksbanken hade förlorat hela sitt förråd af guld? invänder kanske någon. Ja då finge den naturligtvis skaffa sig mera, och därtill har den, så vidt jag vet, ungefär samma utvägar som vanligt, eftersom guldproduktionen alltjämt fortgår till på köpet $\mathrm{i}$ länder, som icke eller blott i ringa mån berörts af kriget - och så länge den stora centraldepån för världens förseende med guld, Bank of England's sedeldepartement, fortfarande står öppen. Huru härmed under krigets fortgång kommer att gestalta sig, är naturligtvis omöjligt att förutse, men så mycket är alldeles visst: efter kriget kommer det icke att vålla den allra ringaste svårighet att återförskaffa allt guld, som vi under mellantiden gjort oss af med. Världens samlade guldförråd är då lika stort som förut eller rättare större - guld är ju, kan man säga, det enda värdeföremål, som icke går åt i krig - och man kommer att bjuda oss det med uppräckta händer i utbyte mot våra varuförråd, om vi blott ha några sådana att afyttra. Skrinlägga vi åter vår guldskatt, ja då ha vi den naturligtvis $i$ behåll, när freden inträder, men på samma gång stå vi utan säljbara varuvärden till långt högre belopp och på samma gång kanhända med en af svält och umbäranden försvagad eller decimerad arbetarbefolkning.

Som sagdt, några positiva råd tillåter jag mig icke att gifva. Men såsom det resultat, hvartill ofvanstående betraktelser, om de eljest äro riktiga, leda, skulle jag vilja uppställa den allmänna satsen: låt guldkassan springa! den springer icke långt, eller $\mathrm{i}$ hvarje fall icke länge; och det enda afgörande hinder för realiserande af denna plan, som jag kan tänka mig, vore, om den tilläfventyrs i hemlighet redan skulle vara verkställd, hvilket jag dock icke har någon anledning att förmoda. Den åsikt åter, som - utan all närmare motivering - fått sitt uttryck i bankutskottets bekanta memorial (n:r I 7), att guldkassan alltid borde bibe- 
hållas vid ett visst minimibelopp, sicke understiga 100,000,000 kr. ", förefaller skäligen meningslöst. Den påminner något litet om den snåle bondens, som gaf sina söner hvar sin plåtsedel att roa sig för på marknaden, men med sträng tillsägelse, att de måste ha pengarna med sig hem igen. Marknadsnöjet torde ha blifvit därefter.

\section{Tillägg.}

Då jag först nedskref ofvanstående uppsats, hade jag ännu den föreställningen, att den fenomenala ökningen under kriget af Engelska bankens guldförråd delvis torde ha berott på den tillfälliga emissionen af sedlar på 20 och Io shillings, hvarigenom banken hade kunnat draga till sig guld från den allmänna rörelsen.

Detta är dock, såsom jag sedermera funnit, icke fallet. För det första är det icke banken utan regeringen, som utfärdat dessa småsedlar, ehuru banken åtagit sig att inlösa dem mot guld liksom sina egna sedlar. Af dylika "currency notes voro den 2 I oktober omkr. 30 mill. $£$ utestående. Regeringen synes ha deponerat $81 / 2$ mill. $£ \mathrm{i}$ banken för att trygga inlösningen af dem, men detta guld ${ }^{1}$ inräknas icke $\mathrm{i}$ bankens metallförråd, utan bokföres särskildt. Hela tillväxten $i$ bankens guldkassa, omkr. 20 mill. $£$ sedan den 22 juli, har alltså kommit från utlandet (delvis i form af guld, som för bankens räkning deponerats i Canada och Sydafrika). Ja än mer: tillfödet af guld utifrån utgjorde under nämnda tidsperiod hela 3 I mill. $£$ netto. ${ }^{2}$ De öfverskjutande I I mill. ha alltså dels användts till bildande af den ofvannämnda extra inlösningsfonden för småsedlarna, dels gått ut $\mathrm{i}$ rörelsen, hvadan det $\mathrm{i}$ England, utanför centralbanken befintliga guldförrådet $i$ verkligheten icke minskats utan tvärtom ökats.

Allt detta kunde förefalla som en paradox, men förklaringen är kanske enkel nog. Ett ställe, där hela världen när som helst kan få ut guld, blir naturnödvändigt också den plats, dit en hvar skickar det guld, som han äger, men icke för tillfället behöfver.

${ }^{1}$ Det kallas i Economists nedan omnämnda berättelse »earmarked against the Currency Notes s.

2 Detta enligt Economists uppgifter. Enligt andra källor, som stått prof. Davidson till buds, bör emellertid denna siffra rätteligen ökas med ytterligare 5 millioner $£$, då alltså öfverskottet skulle bli hela 16 millioner $£$ (i stället för de i texten omnämnda I I mill. $£$ ). 
Sverige är ju icke England, men äfven vi ha genom omständigheternas makt haft att verkställa internationella betalningsförmedlingar till icke ringa omfång och ha så fortfarande. Hade därför vår riksbank icke vid krisens början ängsligt tillslutit sina kassor för guldutväxling, så förefaller det mycket sannolikt, att vi, sedan den första förskräckelsen lagt sig, skulle ha fått se vår guldkassa ökas i stället för minskas - just som i England och därmed varit befriade från en stor del af de kreditbesvärligheter, som vi nu fått dragas med. Äfven engelska banken förlorade under den första paniktiden, intill den 7 augusti, icke mindre än c:a I 3 millioner $£$ i guld, hvilket var nära tredjedelen af dess dåvarande guldförråd; och dess reserv (i banking department) sjönk samtidigt från 29 till icke fullt ro millioner $£$. Men obekymrad härom fortsatte den sina guldutbetalningar med den påföljd, att guldkassan sedan dess så godt som oafbrutet stigit och nu, som sagdt, är större än den någonsin varit. Banken följde helt enkelt, såsom tidningen Economist i sin högintressanta redogörelse (i numret för den 24 oktober) påpekar, sthe old matter of fact philosophy», som erfarenheten har visat vara den enda säkra och fullt förtroendeingifvande: diskontera alla tillfredsställande växlar - naturligtvis mot lämpligt höjd ränta - och betala ut guld till sista halfsovereign. 